\title{
Effect of medical treatment on histological findings in rabbits with acute appendicitis
}

\author{
Gürcan Şimşek, M.D., ${ }^{1}$ Barış Sevinç, M.D., ${ }^{2}$ Yaşar Ünlü, M.D., ${ }^{3}$ İsmail Hasırcı, M.D., ${ }^{1}$ \\ Hüseyin Kurku, M.D., ${ }^{4}$ Ömer Karahan, M.D. ${ }^{5}$ \\ ${ }^{1}$ Department of General Surgery, Konya Training and Research Hospital, Konya-Turkey \\ ${ }^{2}$ Department of General Surgery, Sarıkaya State Hospital, Yozgat-Turkey \\ ${ }^{3}$ Department of Pathology, Konya Training and Research Hospital, Konya-Turkey \\ ${ }^{4}$ Department of Biochemistry, Konya Training and Research Hospital, Konya-Turkey \\ ${ }^{5}$ Department of General Surgery, Necmettin Erbakan University Meram Faculty of Medicine, Konya-Turkey
}

\begin{abstract}
BACKGROUND: Acute appendicitis (AA) is the most common reason for abdominal surgery in the world. The aim of this study was to evaluate the effect of medical treatment on histological findings in rabbits with $A A$.
\end{abstract}

METHODS: Twenty-one male New Zealand rabbits were divided into 3 groups: appendix ligation and medical treatment, appendix ligation and no treatment, and control group, which underwent only laparotomy.

RESULTS: In appendix ligation without treatment group, AA findings were much more severe.

CONCLUSION: Medical treatment reduced inflammation of AA.

Keywords: Acute appendicitis; antibiotic; medical treatment.

\section{INTRODUCTION}

Acute appendicitis (AA) is the most common abdominal surgical emergency all around the world. Lifetime risk of $A A$ is about $7 \%$ to $8 \%$. It is most commonly seen in second and third decades of life. Preferred treatment for AA is surgery. ${ }^{[1]}$

There are, however, several reports about medical treatment for uncomplicated cases of AA such as acute cholecystitis and acute diverticulitis. In fact, medical treatment for AA is not so new. First successful medical treatment was performed during World War II. ${ }^{[2]}$ In 1959, Coldrey reported 474 cases of medical treatment of $\mathrm{AA}$, as well as treatment failure and surgery in 48 cases. ${ }^{[3]}$

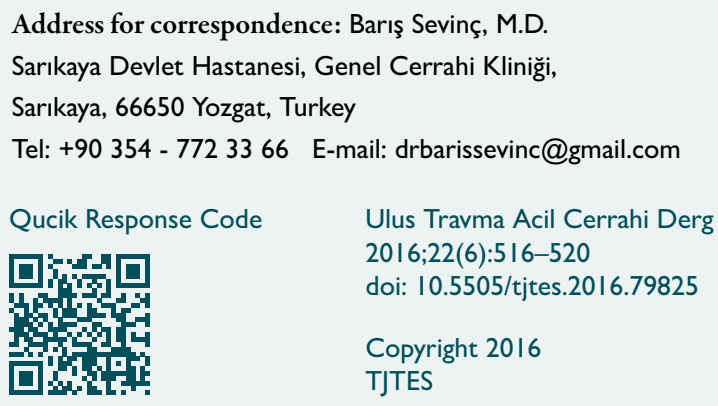

In studies conducted regarding medical treatment of AA, patients have been included according to clinical findings and imaging results. Histological proof of AA was not possible. However, AA is a histopathological term, meaning polymorphonuclear leukocyte invasion at the muscular layer of appendix vermiformis. ${ }^{[4]}$

Histological confirmation of AA is only possible in an experimental study. To our knowledge, there is no previous report of animal experiment regarding medical treatment of AA.

The aim of this study was to evaluate effect of medical treatment on histopathological findings in rabbits with AA.

\section{MATERIALS AND METHODS}

The study was conducted at Necmettin Erbakan University Meram Faculty of Medicine Experimental Medicine Application and Research Center after receiving approval of the ethical committee. Twenty-one male New Zealand rabbits (Oryctolagus cuniculus), weighing between 2050 and $2450 \mathrm{~g}$, were divided into 3 groups:

Group I: Appendix ligation and antibiotic treatment $(n=7)$, Group 2: Appendix ligation, no treatment $(n=7)$, and 
Table I. Histopathological scoring of acute appendicitis

\begin{tabular}{|c|c|c|c|c|}
\hline & $\mathbf{0}$ & $\mathbf{I}$ & 2 & 3 \\
\hline Inflammation & None & Acute inflammation & Phlegmonous inflammation & Gangrenous inflammation \\
\hline Necrosis & None & Limited to mucosa & $\begin{array}{l}\text { Less than half of the } \\
\text { appendix wall }\end{array}$ & Whole appendix wall \\
\hline Residual follicle & None & Minimal & Significant & \\
\hline Inflammation of surrounding fatty tissue & None & Mild & Moderate & Severe \\
\hline Periappendicular abscess & None & Mild & Moderate & Severe \\
\hline \multirow[t]{3}{*}{ Organization and remodeling } & None & Mild & Moderate & Severe \\
\hline & & & Fibroblastic activity & Fibroblastic activity \\
\hline & & & and presence of capillaries & and presence of capillaries \\
\hline
\end{tabular}

Group 3: No appendix ligation, just laparotomy and no treatment $(n=7)$.

AA model described by Menteş et al. was used for the study. [5] All subjects were operated on under general anesthesia induced with ketamine hydrochloride (Ketalar; Pfizer, Inc., NY, NY, USA) and xylazine (Rompun; Bayer AG, Leverkusen, Germany). After shaving the abdomen, skin was disinfected with iodine solution. After midline laparotomy, appendix vermiformis was identified. Base of the appendix was dissected with careful preservation of mesentery and blood vessels (Fig. I). In Group 3, surgery ended at this stage. In Group I and Group 2, ligation with polyglactin sutures was performed to obstruct the appendix. Abdominal wall was closed primarily.

Standard daily diet was provided to subjects during follow-up. Daily ceftriaxone $50 \mathrm{mg} / \mathrm{kg} / \mathrm{d}$ and lincomycin $2 \mathrm{mg} / \mathrm{kg} / \mathrm{d}$ were administered intramuscularly to subjects in Group I. Antibiotherapy was continued for 5 days.

At the end of the fifth day, all subjects underwent appendicectomy under general anesthesia. Blood samples were collected for complete blood count and measurement of C-reactive protein (CRP) levels. During this second operation, macro-

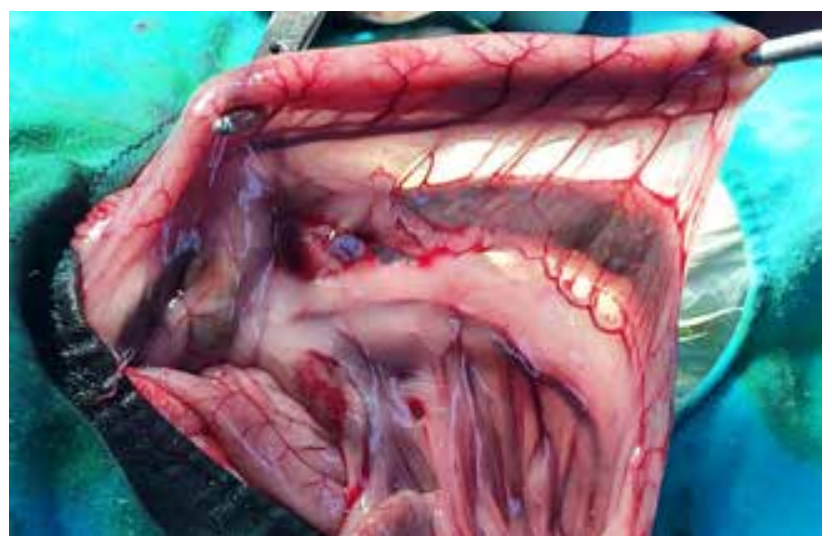

Figure 1. Normal appendix vermiformis, Clamp shows the area to be ligated. scopic findings (perforation, fibrin plaques, abscess formation, etc.) were recorded. Appendicectomy material was collected for histopathological examination.

Histopathological examination was performed by a single, blinded pathologist. As there is no classification method for microscopic findings of $A A$, standard scoring system was used (Table I). Total AA score was calculated and groups were compared in terms of this score.

SPSS software version 20.0 (SPSS, Inc., Chicago, IL, USA) was used for statistical analysis. Independent samples t-test was used for comparison of the groups. Statistical significance level was accepted as 0.05 .

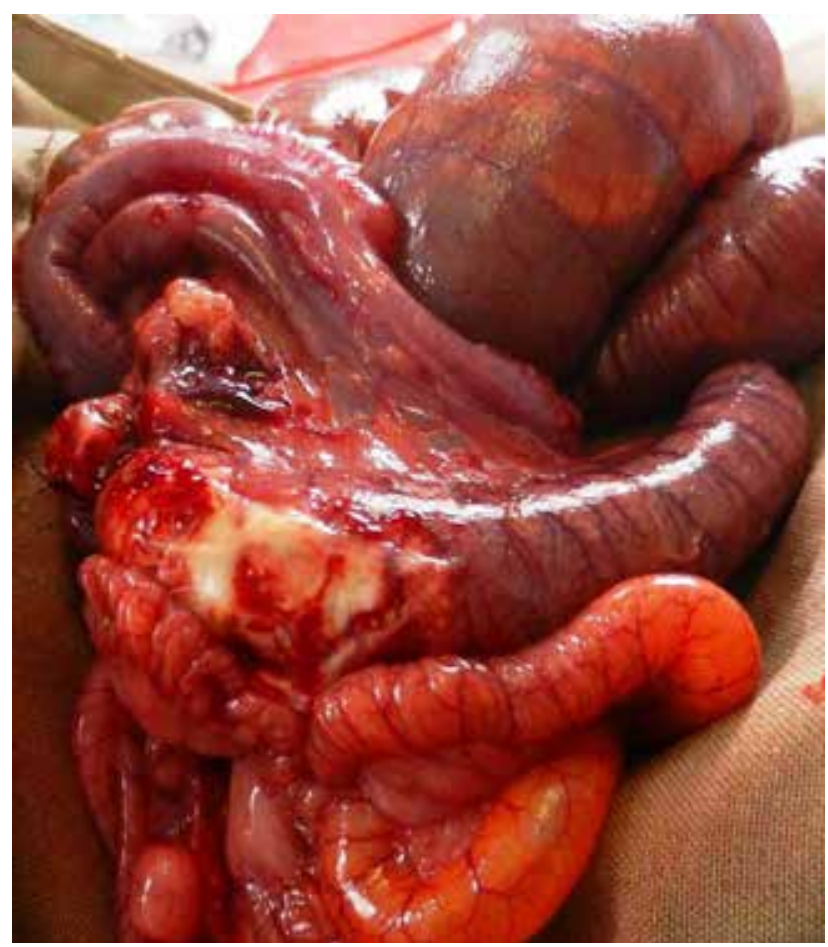

Figure 2. Macroscopic view of acute appendicitis. Fibrin plaques and perforation are seen at the proximal part. 
Table 2. Macroscopic findings of the subjects

\begin{tabular}{lccc}
\hline & Group I & Group 2 & Group 3 \\
\hline Perforation & 0 & 4 & 0 \\
Abscess & 2 & 3 & 0 \\
Generalized peritonitis & 0 & 2 & 0 \\
Fibrin plaques & 2 & 7 & 1 \\
\hline
\end{tabular}

\section{RESULTS}

In terms of leukocyte count and CRP levels, the groups were similar $(p>0.05)$.

During the experiment, 2 subjects in Group 2 died. Postmortem examination revealed perforated appendicitis and generalized peritonitis in both subjects.

No perforation or generalized peritonitis was observed in Group I. However, in Group 2, there was perforation in 4 subjects and generalized peritonitis in 2 (Fig. 2). Localized abscess formation was detected in 2 subjects in Group I and 3 subjects in Group 2. There was no perforation, abscess, or peritonitis found in Group 3 (Table 2).

Acute inflammation was seen in all members of Group I and Group 2 (Figs. 3 and 4). Histological findings of all subjects are provided in Table 3.

In Group 3, histological score was zero; therefore, this group was excluded from statistical analysis. Histological findings in Group 2 were much more severe than those of Group I (Table 4).

\section{DISCUSSION}

Primary factor in pathophysiology of AA is obstruction of

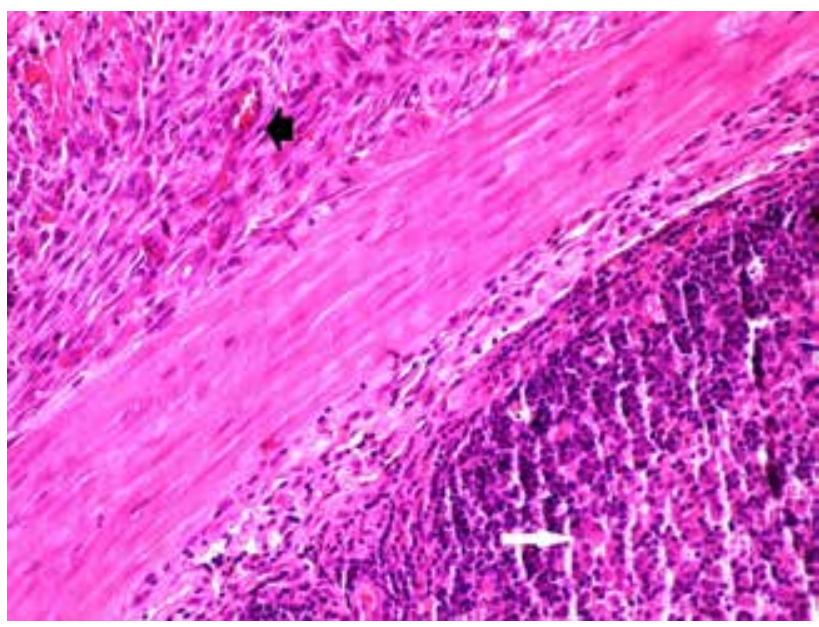

Figure 3. Microscopic view of reactive fibroblastic activity (black arrow) and reactive lymphoid follicle (white arrow). Hematoxylin and eosin stain; $x 100$. appendiceal lumen. Most of the time, obstruction is caused by feces or lymphoid hyperplasia. However, parasites, foreign bodies, and occasionally, cecal or appendiceal tumors can also lead to obstruction. ${ }^{[4]}$ In this experiment, AA was induced with ligation of the base of appendix vermiformis. AA was successfully developed in all subjects in Groups I and 2 .

There are several reports about medical treatment of AA. The first randomized clinical trial regarding medical treatment of AA was conducted by Eriksson et al. in 1995. [6] They reported that medical treatment was as effective as surgery; however, recurrence was major problem. In a randomized prospective trial conducted by Turhan et al., success rate of medical treatment was reported as $82.2 \% .{ }^{[7]}$ In meta-analysis performed by Liu et al., I-year recurrence rate of AA treated medically was reported as $14.2 \% .{ }^{[8]}$ Current experiment showed medical treatment causes suppressed inflammatory reaction; however, as obstruction continues, total cure seems to be impossible. Medical treatment can lead to partial relief in luminal obstruction and clinical findings. Since re-obstruction of the lumen is main cause of recurrence, medical treatment may be especially useful in cases with lymphoid hyperplasia.

In surgical series about AA, negative appendicectomy rate ranges between $9 \%$ and $27 \% .^{\left[{ }^{9]}\right.}$ Even routine use of imaging studies cannot eliminate negative appendicectomies. In a study with routine use of computed tomography, negative appendicectomy rate was reported as $6 \% .{ }^{[10]}$ In studies regarding medical treatment of AA, patients were included according to clinical findings and imaging results. According to data from the literature, about $10 \%$ of patients with medically treated AA are misdiagnosed. In a report comparing surgery and medical treatment, it was noted that false positive diagnosis rate can be determined for surgery cases; however, the same cannot be said for medical treatment. This makes

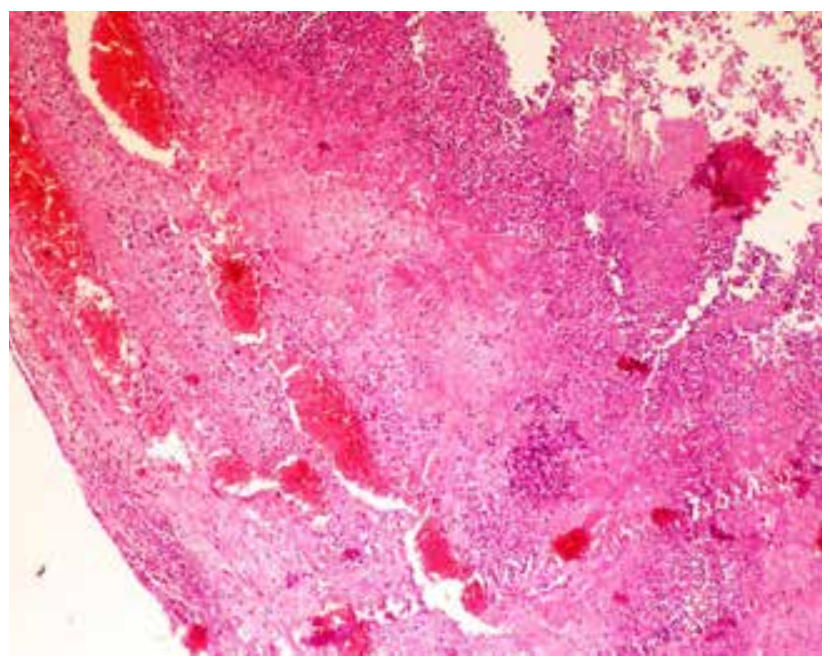

Figure 4. Microscopic view of necrosis zone in an untreated subject. Hematoxylin and eosin stain; $x 100$. 
Table 3. Histopathological evaluation of appendicectomy material

\begin{tabular}{lccccc}
\hline Group Subject & Inflammation & Necrosis & $\begin{array}{c}\text { Inflammation } \\
\text { of surrounding } \\
\text { fatty tissue }\end{array}$ & $\begin{array}{c}\text { Periappendicular } \\
\text { absces }\end{array}$ & $\begin{array}{c}\text { Organization } \\
\text { and } \\
\text { remodeling }\end{array}$ \\
$\begin{array}{c}\text { Total } \\
\text { score }\end{array}$
\end{tabular}

Acute appendicitis +

Medical treatment

1.1
1.2
1.3
1.4
1.5
1.6
1.7

Acute appendicitis +

\begin{tabular}{|c|c|c|c|}
\hline \multirow[t]{7}{*}{ no treatment } & 2.1 & 2 & 2 \\
\hline & 2.2 & 3 & 3 \\
\hline & 2.3 & 3 & 2 \\
\hline & 2.4 & 3 & 2 \\
\hline & 2.5 & 2 & I \\
\hline & 2.6 & 2 & I \\
\hline & 2.7 & 2 & I \\
\hline \multirow[t]{7}{*}{ No intervention } & 3.1 & 0 & 0 \\
\hline & 3.2 & 0 & 0 \\
\hline & 3.3 & 0 & 0 \\
\hline & 3.4 & 0 & 0 \\
\hline & 3.5 & 0 & 0 \\
\hline & 3.6 & 0 & 0 \\
\hline & 3.7 & 0 & 0 \\
\hline \multirow[t]{2}{*}{ Table 4.} & of his & logical scores betv & \\
\hline & & Mean \pm SD & $\mathbf{p}^{*}$ \\
\hline \multicolumn{4}{|c|}{ Total histopathological score } \\
\hline Group 2 & & $8.4286 \pm 2.29907$ & 0.02 \\
\hline \multicolumn{2}{|l|}{ Group I } & $5.57 \mid 4 \pm 1.61835$ & \\
\hline
\end{tabular}

"Independent samples t-test. SD: Standard deviation.

analysis of effectiveness of medical treatment difficult in comparative trials.

In the current study, no perforation or generalized peritonitis was found in medically treated subjects. This indicates medical treatment had beneficial effect of decreasing instances of perforation and septic complications of AA.

The main limitation of the current study is constant luminal obstruction. An experimental model with AA due to lym-

phoid hyperplasia could provide additional information. However, as the first experimental study regarding medical treatment of AA, the results of this study showing beneficial effect on histological findings are important.

Conflict of interest: None declared.

\section{REFERENCES}

1. Stewart B, Khanduri P, McCord C, Ohene-Yeboah M, Uranues S, Vega Rivera F, et al. Global disease burden of conditions requiring emergency surgery. Br J Surg 2014;101:9-22. Crossref

2. Turhan AN, Kapan S. Akut apandisit. In: Ertekin C, Güloğlu R, Taviloğlu K (ed.) Nobel Tip Kitabevi. Acil Cerrahi 2009. p. 301-16.

3. Coldrey E. Five years of conservative treatment of acute appendicitis. J Int coll Surg 1959;32:225-61.

4. Crawford J. (Çeviren: Çevikbaş U, Güllüoğlu M). Ağız boşluğu ve gastrointestinal sistem. In: Kumar V, Cotran RS, Robbins SL (Ed.) Çeviri Ed: Çevikbaş U. Basic pathology. 6th ed. Nobel Tip Kitabevleri; 2000. p. 514.

5. Menteş Ö, İde T, Akdağ E, Balkan M, Öngörü Ö, Kozak O ve ark. Akut apandisit: Apendiksin bağlanması (Tavşanlarda deneysel model). Gülhane Tip Dergisi 2008;50:27-9.

6. Eriksson S, Granström L. Randomized controlled trial of appendi- 
cectomy versus antibiotic therapy for acute appendicitis. Br J Surg 1995;82:166-9. Crossref

7. Turhan AN, Kapan S, Kütükçü E, Yiğitbaş H, Aygün E. Akut apandisitte nonoperatif takip ve tedavi. Bakırköy Tip Dergisi 2006;2:134-6.

8. Liu K, Fogg L. Use of antibiotics alone for treatment of uncomplicated acute appendicitis: a systematic review and meta-analysis. Surgery 2011;150:673-83. Crossref
9. Bhangu A, Søreide K, Di Saverio S, Assarsson JH, Drake FT. Acute appendicitis: modern understanding of pathogenesis, diagnosis, and management. Lancet 2015;386:1278-87. Crossref

10. SCOAP Collaborative, Cuschieri J, Florence M, Flum DR, Jurkovich GJ, Lin P, Steele SR, et al. Negative appendectomy and imaging accuracy in the Washington State Surgical Care and Outcomes Assessment Program. Ann Surg 2008;248:557-63.

\section{DENEYSEL ÇALIŞMA - ÖZET}

\section{Tavşanlarda oluşturulan akut apandisit modelinde medikal tedavinin} histopatolojik bulgular üzerindeki etkisi

\section{Dr. Gürcan Şimşek, ${ }^{1}$ Dr. Barış Sevinç, ${ }^{2}$ Dr. Yaşar Ünlü, ${ }^{3}$ Dr. İsmail Hasırcı,, ${ }^{1}$ Dr. Hüseyin Kurku, ${ }^{4}$ Dr. Ömer Karahan ${ }^{5}$}

${ }^{1}$ Konya Eğitim ve Araştırma Hastanesi, Genel Cerrahi Kliniği, Konya

${ }^{2}$ Sarıkaya Devlet Hastanesi, Genel Cerrahi Kliniği, Yozgat

${ }^{3}$ Konya Eğitim ve Araştırma Hastanesi, Patoloji Kliniği, Konya

${ }^{4}$ Konya Eğitim ve Araştırma Hastanesi, Biyokimya Laboratuvarı, Konya

${ }^{5}$ Necmettin Erbakan Üniversitesi Meram Tıp Fakültesi, Genel Cerrahi Anabilim Dalı, Konya

AMAÇ: Akut apandisit dünyada genel cerrahların karşılaştığı en sık akut karın nedenidir. Bu çalışmada, akut apandisit oluşturulan tavşanlarda antibiyotik tedavisinin akut apandisitte ortaya çıkan histopatolojik bulgular üzerine etkisinin değerlendirilmesi amaçlandı.

GEREÇ VE YÖNTEM: Çalışma için 2 I adet Yeni Zelenda cinsi (Oryctogaluscuniculus), erkek ve ağıılıkları 2050-2450 gram arasında değişen tavşan kullanıldı. Denekler üç gruba ayrıldı: Grup I: Apendiks ligasyonu yapılan ve antibiyotik tedavisi verilen grup ( $n=7)$, Grup 2: Apendiks ligasyonu yapilan ama antibiyotik tedavisi verilmeyen grup $(n=7)$, Grup 3: Apendiks ligasyonu yapılmayan ve antibiyotik tedavisi verilmeyen grup (sham grubu) $(\mathrm{n}=7)$.

BULGULAR: Grup I ve Grup 2 arasında yapılan istatistiksel analiz sonucunda Grup 2'de ortaya çıkan histopatolojik değişiklikler Grup I'den anlamlı olarak daha şiddetliydi.

TARTIŞMA: Antibiyotik tedavisi akut apandisitte histolojik olarak enflamasyonun şiddetini azaltmaktadır.

Anahtar sözcükler: Antibiyotik tedavisi; apandisit; medikal tedavi.

Ulus Travma Acil Cerrahi Derg 2016;22(6):516-520 doi: 10.5505/tjtes.2016.79825 